\title{
The different audiences of science communication: A segmentation analysis of the Swiss population's perceptions of science and their information and media use patterns
}

Schäfer, Mike S ; Füchslin, Tobias ; Metag, Julia ; Kristiansen, Silje Theresa ; Rauchfleisch, Adrian

\begin{abstract}
Few studies have assessed whether populations can be divided into segments with different perceptions of science. We provide such an analysis and assess whether these segments exhibit specific patterns of media and information use. Based on representative survey data from Switzerland, we use latent class analysis to reconstruct four segments: the "Sciencephiles," with strong interest for science, extensive knowledge, and a pronounced belief in its potential, who use a variety of sources intensively; the "Critically Interested," also with strong interest and support for science but with less trust in it, who use similar sources but are more cautious toward them; the "Passive Supporters" with moderate levels of interest, trust, and knowledge and tempered perceptions of science, who use fewer sources; and the "Disengaged," who are not interested in science, do not know much about it, harbor critical views toward it, and encounter it-if at all-mostly through television.
\end{abstract}

DOI: https://doi.org/10.1177/0963662517752886

Posted at the Zurich Open Repository and Archive, University of Zurich

ZORA URL: https://doi.org/10.5167/uzh-159003

Journal Article

Accepted Version

Originally published at:

Schäfer, Mike S; Füchslin, Tobias; Metag, Julia; Kristiansen, Silje Theresa; Rauchfleisch, Adrian (2018). The different audiences of science communication: A segmentation analysis of the Swiss population's perceptions of science and their information and media use patterns. Public Understanding of Science, 27(7):836-856.

DOI: https://doi.org/10.1177/0963662517752886 
Full Publication in "Public Understanding of Science" at: https://doi.org/10.1177\%2F0963662517752886

The Different Audiences of Science Communication. A Segmentation Analysis of the Swiss Population's Perceptions of Science and their Information and Media Use Patterns

\author{
Mike S. Schäfer and Tobias Füchslin \\ University of Zurich, Switzerland \\ Julia Metag \\ Université de Fribourg, Switzerland \\ Silje Kristiansen \\ Northeastern University, USA \\ Adrian Rauchfleisch \\ University of Zurich, Switzerland
}

Cite as: Schäfer, M. S., Füchslin, T., Metag, J., Kristiansen, S., \& Rauchfleisch, A. (2018). The different audiences of science communication: A segmentation analysis of the Swiss population's perceptions of science and their information and media use patterns. Public Understanding of Science, 27(7), 836-856. https://doi.org/10.1177/0963662517752886

\begin{abstract}
Few studies have assessed whether populations can be divided into segments with different perceptions of science. We provide such an analysis and assess whether these segments exhibit specific patterns of media and information use. Based on representative survey data from Switzerland, we use latent class analysis to reconstruct four segments: The "Sciencephiles", with strong interest for science, extensive knowledge and a pronounced belief in its potential, who use a variety of sources intensively. The "Critically Interested", also with strong interest and support for science but with less trust in it, who use similar sources but are more cautious towards them. The "Passive Supporters" with moderate levels of interest, trust and knowledge and tempered perceptions of science, who use fewer sources. The "Disengaged", who are not interested in science, do not know much about it, harbor critical views towards it, and encounter it - if at all - mostly through television.
\end{abstract}




\section{Introduction}

Many scholars have scrutinized public perceptions of science in recent decades (for an overview see Besley, 2013). Largely based on survey data, this research has shown that different sociodemographic groups differ in their knowledge about, support for or trust in science (e.g. OST \& The Wellcome Trust, 2000).

In light of such differences, it is likely that larger segments of the population can be reconstructed which differ in their perceptions of science. Yet only few studies have investigated such science-related segmentation (Guenther \& Weingart, 2017; Kawamoto, Nakayama \& Saijo, 2013; Nisbet \& Markowitz, 2014; OST, 2005; OST \& The Wellcome Trust, 2000). Therefore, we provide a segmentation analysis of the Swiss population, asking, firstly, what segments of the population can be reconstructed which differ in their perceptions of science (RQ1)?

In addition, the analysis of such segments' patterns of media and information use seems helpful. For many people, media are important sources for information about science (e.g. National Science Board, 2014), albeit they seemingly turn to them with different intentions and in different ways (e.g. Kahlor \& Rosenthal, 2009). Information about segment-specific patterns of information use could therefore be helpful for devising communication strategies surrounding science. So far, however, few segmentation analyses on science included communicative patterns, and those that did only considered general media use without describing it in detail. Therefore, our second research question asks how people belonging to the reconstructed segments differ in their patterns of science-related information and media use (RQ2).

\section{Conducting Segmentation Analyses in Science Communication}

\subsection{Perceptions of Science and Science Communication}

Research on the relationship between science and the public has intensified since the 1980s, with survey studies being of particular relevance. Early on, they were driven by the "deficit model" (e.g. Bucchi, 2008; Durant, 2003) of science communication. Large-scale surveys were established in the UK, the US and in Europe to assess the public's knowledge - its "scientific literacy" (Miller, 1983) - and its perceptions of science (e.g. Eurobarometer, 2001; OST, 2005; OST \& The Wellcome Trust, 2000). Even when, later on, the deficit model made way for more dialogical models, survey research remained important and even expanded in many countries (cf. Besley, 2013).

This research has repeatedly shown that subgroups of the population differ in their perceptions of science. Differences in general attitudes towards science were found, for example, between people 
from urban and rural areas or with different educational levels in Japan (Kawamoto et al., 2013). Research also showed that perceptions of specific research fields, like animal experimentation (Roten, 2013), nuclear energy (Kristiansen, Bonfadelli, \& Kovic, 2016), or nanotechnology (Lee, Scheufele, \& Lewenstein, 2005) vary by sex, age, education or religiosity in countries like the US or Switzerland. Similarly, knowledge about science - both in general (e.g. Nisbet et al., 2002) and about specific fields (Kristiansen et al., 2016) - was shown to differ between sociodemographic groups.

The variation in these perceptions "represents a significant challenge for scientists, policy makers, and others tasked with effective communication[, as c]ertain types of messages may be enthusiastically embraced by some members of the general public, but elicit indifference or outrage from others." (Hine et al., 2014, p. 441). However, the question remains largely unanswered what larger patterns can be found behind these individual-level differences. Few researchers have examined which segments of the population can be reconstructed that differ in their perceptions of science. Identifying such segments and their profiles, however, would provide "policymakers, researchers, and communication practitioners with comprehensive and detailed knowledge of the target population and its subgroups" (Detenber, Rosenthal, Liao, \& Ho, 2016, p. 4738). It would give them "an important strategic planning asset [...] for making decisions about how to best allocate limited communication resources" (Hine et al., 2014, p. 442).

While research has shown segmentations among the public for issues such as climate change (for an overview see Hine et al., 2014), energy (Sütterlin, Brunner, \& Siegrist, 2011) or health (e.g. Maibach, Weber, Massett, Hancock, \& Price, 2006) repeatedly and in different countries, segmentations with regards to science have rarely been analyzed. The few exceptions from Japan, South Africa, the UK and the US differ in their approaches: While Kawamoto et al. (2013) segment the Japanese population according to a broad understanding of scientific literacy and of respondents' interests in non-scientific topics as well, surveys in the U.S. and the UK focus on science-related perceptions (OST, 2005; OST \& The Wellcome Trust, 2000; Research Councils UK, 2008), and a South African study uses sociodemographic characteristics as the basis for segmentation (Guenther \& Weingart, 2017). Accordingly, their findings are difficult to compare.

Segmentation analyses are also missing with regards to patterns of science-related information and media use. While the science of science communication has become an important field with a substantial and rising number of studies (Schäfer, 2012), it mirrors research on public perceptions of science with regards to the questions posed here: Many studies have shown that uses and effects of science communication differ considerably between, for example, age groups, gender, and education 
levels. For example, science magazines or science TV shows are used to different degrees by different age groups, or by people with different education levels in the US (Nisbet et al., 2002), and sciencespecific information and media use patterns differ strongly between urban and rural areas in Latin America (Hurtado \& Cerezo, 2012). Similar differences have been documented for the attendance of science events and museums and for personal conversations (e.g. Research Councils UK, 2008, 12ff.). But, again, whether and how these differences can be organized along different population segments has not been analyzed often. Only few segmentation analyses have included communicative patterns (e.g. Leiserowitz, Maibach, Roser-Renouf, \& Smith, 2010; Metag, Füchslin, \& Schäfer, 2017), and even fewer focused on science communication (Guenther \& Weingart, 2017; Kawamoto et al., 2013; OST, 2005; OST \& Wellcome Trust, 2000; Research Councils UK, 2008). But those found differences between population segments. They show, for example, that British "technophiles" use legacy media extensively to get information about science while the "not for me" segment rarely encounters scientific content (OST \& Wellcome Trust, 2000, 45, 62). Yet, these studies only consider a limited number of media and information variables, often restricting themselves to general media use with generic categories like "the internet" (e.g. Guenther \& Weingart, 2017; Research Councils UK, 2008) and omitting respondents' evaluation of sources (e.g. Eveland, 2001) or their motivations for tending to them (cf. Kahlor \& Rosenthal, 2009).

\subsection{Types of segmentation analyses}

Generally, segmentation analyses aim to "divide the general public into relatively homogeneous, mutually exclusive subgroupings" (Hine et al., 2014, p. 442). In communication science or (social) marketing, analyses of audience segmentation are often undertaken so that in a second step, "appropriate message design and communication strategies can be developed to influence attitudes and behaviors" (Slater, 1996, p. 272). ${ }^{1}$

Segmentation analyses have employed different research designs ranging from qualitative interview and focus group studies to standardized surveys and, more recently, analyses of social media. Among them, large-scale quantitative survey analyses have been described as particularly advantageous if the identified segments are to be representative for a larger population, with national probability samples being the "gold standard" (Hine et al., 2014, p. 452).

\footnotetext{
${ }^{1}$ In marketing, segmentation analyses have been used to inform advertising and to influence consumer behavior and buying decisions (for overviews see Yankelovich and Meer (2006) and Lotenberg et al. (2011)).
} 
Three basic logics have been applied in order to select variables for segmentation: Older studies often used sociodemographic variables for segmentation (Dibb \& Simkin, 2009). Studies "discriminate[d] between audience or market groups on the basis of easily accessed variables, such as demographics (education, race, income, gender)" (Slater, 1996, p. 269) which were later "crosstabbed with media use and some key psychosocial variables such as involvement and behavior" (Slater, 1996, 268f.). The usefulness of this approach, however, is limited to the few cases where sociodemographic characteristics are strong predictors of the attitudinal or behavioral variables of interest (Yankelovich \& Meer, 2006, 123f.).

Recent segmentation analyses have mostly used one of two approaches (for an overview see Lotenberg Schechter, \& Strand, 2011): On the one hand, they used respondents' attitudes towards a topic or object, i.e. "psychographic" variables (Wind, 1978, 319f.), for segmentation. Such studies are available, for example, for respondents' attitudes towards health (Noar, Benac, \& Harris, 2007), energy (Sütterlin et al., 2011) or climate change (Hine et al., 2014). On the other hand, scholars from fields like marketing have criticized that while segmentations based on psychographic variables "may capture some truth about real people's lifestyles, attitudes, self-images and aspirations", they are criticized for being weak at predicting behavior (Yankelovich \& Meer, 2006, p. 124). As a result, they have argued for segmentation analyses centered around behavioral data (Yankelovich \& Meer, 2006, 125f.), or around channels of communication (cf. Lotenberg et al., 2011).

This criticism, however, sells the advantages of 'psychographic' segmentations short. These have shown, e.g., that segments are stable over time (e.g. Leiserowitz, Maibach, Roser-Renouf, Feinberg, \& Howe, 2013), that they correlate with peoples' general values (e.g. Roser-Renouf, Maibach, Leiserowitz, Feinberg, \& Rosenthal, 2016), and that they can be better predictors of science-related policy support than political ideology and sociodemographic variables (Maibach, Leiserowitz, RoserRenouf, \& Mertz, 2011). Moreover, they have demonstrated that people in different segments also differ in their media diets (Metag et al., 2017), and that segmentation can improve communication efforts by facilitating targeted messages (Noar et al., 2007). Therefore, and because almost no segmentation analyses about the attitudes towards and perceptions of science exist so far, we will segment 'psychographically'. In a second step, we will then take communication and media-related variables into account.

The degree to which segmentation analyses are theoretically guided differs (cf.Dibb \& Simkin, 2009). There are studies which are based on coherent theoretical frameworks, but they are uncommon due to the lack of specific theoretical models for science communication (Hine et al., 2014, p. 447) and their 
sometimes limited use for planning communication campaigns (Slater, 1996, p. 273). In contrast, many segmentation analyses employ an "atheoretical 'whatever works"' (Hine et al., 2014, p. 448) approach without specifying a conceptual basis for variable selection (cf. Dibb \& Simkin, 2009). The middle ground are studies which provide rationales for selecting individual variables based on earlier analyses and different concepts in science communication (cf. Hine et al., 2014; Metag et al., 2017). These studies make up the majority of segmentation analyses in science-related fields and offer the advantage that different theoretical concepts can be taken into account. We employ this approach as well.

\subsection{Relevant Factors for a Segmentation Analysis of Science Communication}

Our analysis derives the core dimensions it uses for segmentation from the large field of sciencerelated survey research in general (Besley, 2013) and the small number of previous segmentation analyses (e.g. Kawamoto et al., 2013; OST, 2005).

The first dimension concerns general attitudes towards science. Social psychologists (Ajzen, 1989) have proposed a broad understanding of attitudes covering cognitive, affective and conative aspects:

- The cognitive aspect of attitudes refers to information about an attitude object, or perceptions of it (Ajzen, 1989, 242f.). With regards to science, it has most often been used as knowledge about science, or "scientific literacy" (Kawamoto et al., 2013; Miller, 1983), which referred to factual knowledge about scientific findings early on and has since been extended to also include knowledge about scientific procedures. A second cognitive aspect is people's interest in science (Kawamoto et al., 2013, p. 680).

- The affective aspect of attitudes "has to do with feelings towards the attitude object" (Ajzen, 1989, p. 243). Due to its inherently non-rational, affective nature (Engdahl \& Lidskog, 2014; Schäfer, 2016), trust in science and its protagonists has been used as such an affective attitude towards science (Lee et al., 2005).

- The conative aspect refers to "behavioral intentions ... or actions with respect to the attitude object" (Ajzen, 1989, p. 244). With regards to science, this dimension has often been operationalized as people's search for information about scientific issues (cf. Bauer, 2016; Eurobarometer, 2005). With the advent of citizen science, a second conative facet has been included in some surveys: people's desire to partake in research projects themselves (Wissenschaft Im Dialog, 2015). 
The second dimension refers to people's reservations and beliefs with regards to the "promise of science" (Bauer, 2016). To capture these hopes and concerns about science and its potential to solve societal problems, survey questions already exist that were developed and tested in several countries (e.g. Eurobarometer, 2005; National Science Board, 2014; Prpić, 2011).

Thirdly, people's subjective norms with regards to science and science communication have been described as relevant for their perceptions of science, and have been shown to have behavioral consequences (Ajzen, 2001; Bamberg \& Möser, 2007):

- The first are normative preferences regarding the relation of science and society. People have different assessments regarding the necessity of science in general (Eurobarometer, 2010), its need for public funding (Wissenschaft Im Dialog, 2015), its role in political decision-making (Bauer, 2016), the role of the public in defining science's agenda (Wissenschaft Im Dialog, 2015) or the duty of scientists to inform the public about their work (Mejlgaard \& Stares, 2010).

- The second normative facet concerns people's own norms (Ajzen, 2001, 2002) with regards to being informed about science. Descriptive norms refer to the extent to which people believe one should be informed about science. Injunctive norms describe to what extent people think that they are expected to be informed about science by their peers (Kahlor, Dunwoody, Griffin, \& Neuwirth, 2006).

We will use these dimensions to segment the Swiss population according to their perceptions of science. Subsequently, we analyze whether these segments differ in their information and media use. As research has shown that people use different sources for information about science (for an overview see Metag, 2017), we will take different sources and individual assessments of these into account. This will provide more detailed information about information and media use than surveys like the Eurobarometer (2010) or the Science and Engineering Indicators (National Science Board, 2014):

- Firstly, news media like TV, radio or printed publications such as science magazines have been shown to be important sources of information about science for many people (e.g. Nisbet et al., 2002). In addition, audience segments that were described for issues like climate change (Leiserowitz et al., 2010; Metag et al., 2017) have been shown to differ in their news media use.

- Secondly, online sources and social media have gained importance with regards to scientific issues (Brossard, 2013; Brossard \& Scheufele, 2013; Schäfer, 2017). This includes websites as well as social media like Wikipedia, Facebook, video portals, blogs and online forums. 
- Thirdly, sources of information beyond news and online media have to be considered, as research has shown that some people inform themselves about scientific issues in non-fiction books, museums and science centers, zoos and aquariums, talks or science-related events (e.g. BBVA foundation, 2011; Eurobarometer, 2010; OST \& The Wellcome Trust, 2000).

- Apart from the frequency of contact, fourthly, research has demonstrated that the ways in which people turn to, perceive and evaluate science-related information influence the outcome of science communication and attitudes toward science. Building on this research, and on concepts from communication science such as information seeking or uses and gratifications approaches, we also analyze people's evaluation of media content, their attentiveness when consulting those sources (Eveland, 2001; Eveland Jr, Hutchens, \& Shen, 2009) and their motivations and expected gratifications for using them (Kahlor \& Rosenthal, 2009).

In addition, sociodemographic characteristics have been shown to be associated with perceptions of science and information behaviors (Besley, 2013; Nisbet et al., 2002).

\section{Data and Methods}

\subsection{Data}

We use data from the representative "Science Barometer Switzerland" ("Wissenschaftsbarometer Schweiz") survey from 2016. It assesses the Swiss population's attitudes towards, beliefs in and knowledge about science and research. Based on public telephone listings ( $90 \%$ landlines, $10 \%$ mobile), households were randomly selected, household members chosen according to sex and age quotas, and interviewed using computer assisted telephone interviews (CATI). 1,051 respondents participated (651, 200, 200 from the German-, French- and Italian-speaking parts of the country). The final sample was weighted regarding cantons ${ }^{2}$, size of living area, gender, age, education, occupation and household size.

\section{- TABLE 1 HERE -}

\subsection{Measurements}

Attitudes towards science were measured regarding cognitive, affective and conative aspects (see Table 1 for detailed information).

\footnotetext{
${ }^{2}$ Cantons are federal entities in Switzerland similar to U.S. states.
} 
- To assess the cognitive aspect, we measured respondents' knowledge about science. Often, quiz questions were used in surveys to assess knowledge (Kawamoto et al., 2013; Miller, 1983), but they have been criticized extensively (e.g. Pardo \& Calvo, 2002, 2004). Taking up the major criticisms, we used the traditional quiz format in adapted form. First, we included questions about arts and humanities, textbook and applied scientific knowledge (cf. Pew Research Center, 2013) and also about the process of science. Second, we moved from the established dichotomous "correct-false" answer format, which gives respondents a 50\% random chance to answer correctly, to a format allowing respondents to indicate the level of certainty in their answers (cf. BBVA foundation, 2011, 19ff.). ${ }^{3}$ Answers for the 11 items from the "Science Barometer Switzerland" were combined in an index: Correct answers gave respondents one point for the "likely" and two points for the "definitely" version. Incorrect or "do not know" answers were assigned zero points. The index value is the arithmetical mean of points per question, ranging from 0 to 2 . In addition to knowledge, we asked for respondents' interest in science, employing a question that was widely used in several surveys (e.g. BBVA foundation, 2011; Eurobarometer, 2010; OST \& The Wellcome Trust, 2000).

- The affective aspect of attitudes was measured by asking respondents for their general trust in science (Lee et al., 2005) as well as for their assessment of whether science plays an important role in their lives.

- We assessed the conative aspect with two questions asking whether respondents search for information about science actively and whether they would like to be personally involved in a research project once (cf. Wissenschaft Im Dialog, 2015).

Respondents' reservations and beliefs with regards to science were assessed with sets of questions used in international surveys before. We used an adapted variant of the shortened version developed by Prpić (2011).

People's norms with regards to science and science communication were assessed, firstly, by combining questions from different surveys (Besley, 2013; Eurobarometer, 2010; Nisbet et al., 2002, p. 591) asking for respondents' preferences regarding the relation of science and society. Furthermore, people's own informational norms with regards to science were assessed (Kahlor et al., 2006).

\footnotetext{
${ }^{3}$ These changes were crosschecked both with a recoded, traditional "correct-false" scale for all 11 questions and with a recoded version containing only those five questions which were taken verbatim from earlier studies. Our version of the science quiz correlated strongly with both other measures $\left(0.899^{* *}\right.$ and $\left.0.723^{* *}\right)$, and the differences in knowledge about science between the segments which are reported below were similar across all quiz versions.
} 
To contextualize attitudes towards science we asked respondents what they associated with the survey's topic, i.e. with "science and research". The survey contained an open question asking for up to three associations. Most respondents provided at least one association. These were recoded into disciplines according to the OECD (2007) taxonomy and into general descriptions of science.

In addition, we analyzed respondents' patterns of information and media use. We asked through which mass media they get into contact with science (BBVA foundation, 2011; Schäfer \& Taddicken, 2015). Respondents' who indicated to get into contact with science via the internet were asked detailed questions about online platforms and social media (cf. OST \& The Wellcome Trust, 2000; Pew Research Center, 2013). In addition, we included sources such as museums, zoos, aquariums, science-related events, or non-fiction books (e.g. BBVA foundation, 2011; OST \& The Wellcome Trust, 2000).

We also asked for qualitative information about media use: respondents' assessments of media coverage's ability to explain science's relevance as well as their evaluation of the extent, comprehensibility and trustworthiness of media reporting (mostly based on Macedo-Rouet, Rouet, Epstein, \& Fayard, 2003; Tsfati, Cohen, \& Gunther, 2011), their attentiveness when encountering scientific topics in media (adapting a question from Fredin, Kosicki, \& Becker, 1996) and their motivations for tending to scientific content (adapting scales from Rössler, 2011, 4ff.).

Eventually, we included sociodemographic characteristics (age, sex and education, (Besley, 2013; Nisbet et al., 2002), religiosity (OST \& The Wellcome Trust, 2000), political orientation (cf. Nisbet et al., 2002) and an index of people's personal or professional proximity to science (BBVA foundation, 2011). For this index, respondents were first asked whether they were scientists themselves. If not, they were asked whether they "personally knew a scientist", "have family members that study or studied at university level" and "come in contact with science through their work". Each affirmative answers resulted in one index-point. Scientists were directly assigned four points, resulting in a sum-index from 0 to 4 .

\subsection{Method}

Segmentation analyses aim to split populations into homogenous subgroups that differ with regards to relevant variables. Such analyses commonly use one of two approaches: Some employ factor analysis first to reduce variable complexity and administer distance-based clustering methods such as hierarchical or k-means clustering afterwards (Kawamoto et al., 2013; OST, 2005; OST \& The Wellcome Trust, 2000). Others cluster variables in their original forms directly, mostly using a model-based 
method such as latent class analysis (LCA; Maibach et al., 2011; Morrison, Duncan, Sherley, \& Parton, 2013).

The main advantage of the first approach is the reduction of the number of variables, which simplifies cluster interpretation. It also results in continuous variables, thus lends itself to distance-based clustering methods. The disadvantage, however, is a substantial loss of information. Factor analyses are likely to exclude unsuitable variables, while other variables will only be maintained with low factor loadings.

LCA, in turn, has several advantages: It can handle any variable level, large numbers of variables (Magidson \& Vermunt, 2002b; McLachlan \& Peel, 2004) and higher numbers of missing values (Maibach et al., 2006). Since cluster solutions are based on a statistical model, measures to compare model fit can be used, and the predictive power of indicators is denoted (Linzer, Lewis, \& others, 2011). On top, LCA has been shown to outperform distance-based measures such as k-means (Magidson \& Vermunt, 2002a). Therefore, LCA has been described as the "preferred strategy for generating audience segments" (Hine et al., 2014). We apply it as well.

Using the above mentioned variables covering attitudes towards science, reservations and beliefs and science-related informational norms, we determined optimal solutions from two up to 15 clusters using LatentGold 5.1 software (Vermunt \& Magidson, 2016). 5,000 random sets of starting values were entered into the algorithm to ensure validity and robustness of each solution. BIC values showed twoor three-cluster solutions to be unfavorable. All other solutions were on similar levels. The four-cluster solution offered the clearest interpretation ${ }^{4}$. It yielded $94,7 \%$ correctly assigned cases in discriminant analysis and conserved the full representative sample size $(\mathrm{N}=1051)$. We assessed segment means through modal attribution of cases, i.e. each case was assigned to its most probable segment. For more than $99 \%$ of respondents, the likelihood of belonging to one segment exceeded $50 \%$. Furthermore, the overall hit-rate - defined as the sample mean of all respondents' posterior probabilities (cf. Gollwitzer, 2012) - reached $89 \%$.

\section{Results}

4.1 The segmentation of the population: four perspectives on science

\footnotetext{
${ }^{4}$ Before using latent class analysis, we also ran a factor analysis with a subsequent cluster analysis. It also resulted in a four-cluster solution with an interpretation similar to the one presented in this article.
} 
The four population segments that were reconstructed have distinct perceptions of science. Figure 1 shows the means of the four segments along the 20 cluster variables as well as their $\mathrm{R}^{2}$ values, indicating which variables are more differentiating between the segments than others.

Figure 1

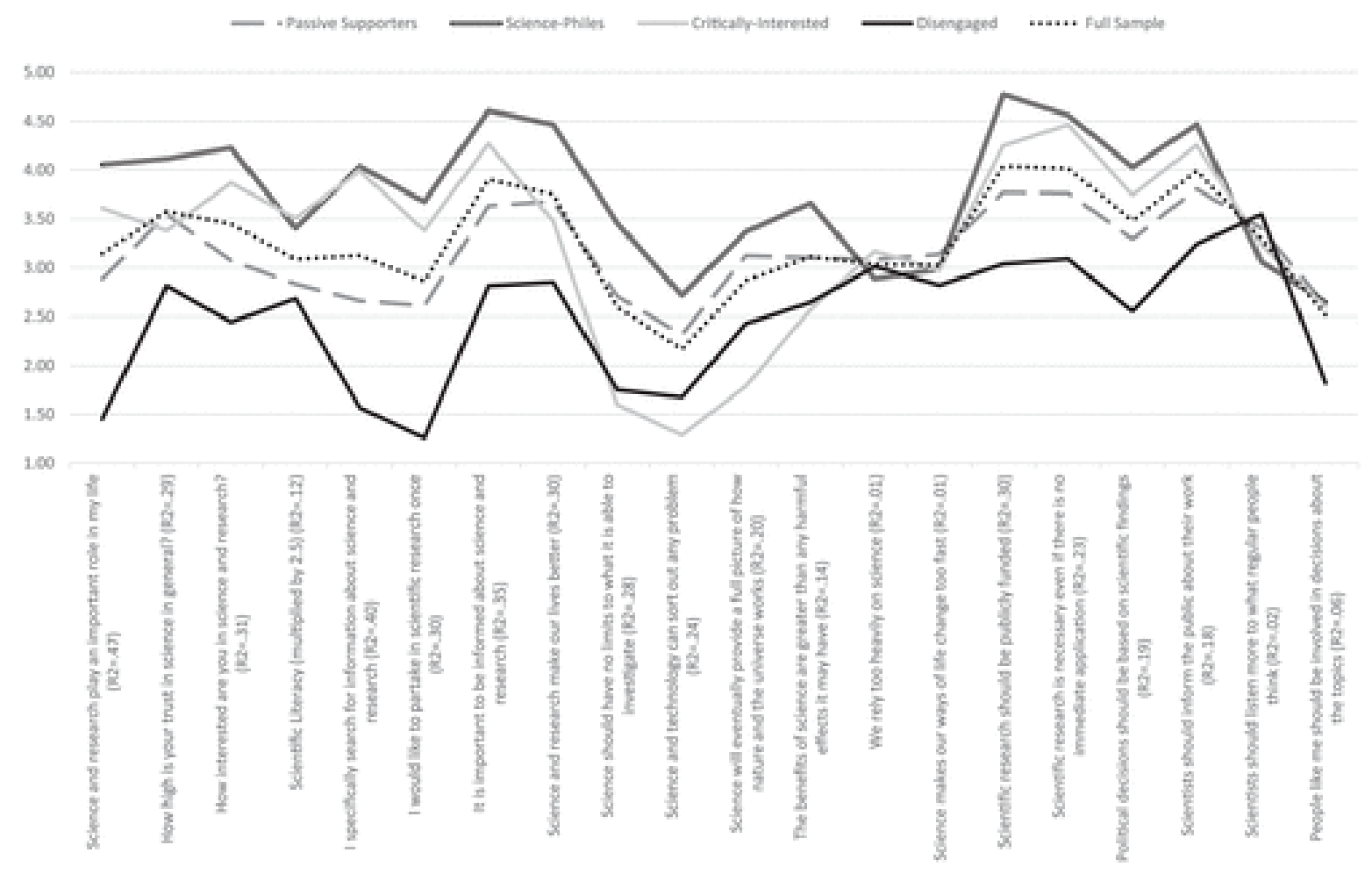

1. The "Sciencephiles" $(n=292)$ form the second largest segment representing $27,8 \%$ of the Swiss population. They mostly associate "science and research" with the natural sciences (which account for $22,5 \%$ of their associations), followed by medicine $(20,7 \%)$, engineering $(13,2 \%)$ and, albeit less often, the social sciences (5,3\%). The "Sciencephiles" know a lot about science, and exhibit the highest means on almost all variables regarding attitudes and beliefs towards science and research: They feel that science is important in their lives, have a strong interest and high trust in it. More than all other segments, they think it is important to be informed about science, actively seek information about it and are the most interested in partaking in research projects. Also, they are highly supportive of science, think scientists should inform the public and that scientific findings should influence political decisions.

Regarding the promises of science, they are the most hopeful and least critical. They strongly believe science improves our lives and oppose research constraints. Even though they do not 
think science can solve every problem, they are the most optimistic segment regarding this question.

2. The "Critically Interested" segment encompasses $17,2 \%(n=181)$ of all respondents. When they hear "science and research", they also mostly associate the natural sciences $(22,6 \%)$ and medicine $(20,7 \%)$, followed by engineering $(12,0 \%)$ and - rather strongly compared to all other segments - the social sciences $(6,9 \%)$. Their knowledge about and attitudes towards science are similar to the "Sciencephiles"'. The main difference is that they trust science considerably less, and have stronger reservations regarding science's promises. While the "Critically Interested" think that science is important in our lives, they also strongly favour research constraints, think science cannot solve every problem, and that it will not provide a full picture of the world eventually.

Despite these criticisms, the "Critically Interested" are only slightly less supportive of science than the "Sciencephiles". They do not question public funding or the necessity of basic research, think research findings should be incorporated in political decisions, and want to be informed about scientists' work.

3. The "Passive Supporters" ( $n=437,41,5 \%)$ are the largest group. For them, "science and research" is mostly medicine $(22,3 \%)$, followed by the natural sciences $(17,9 \%)$ and engineering $(9,5 \%)$. Social sciences $(3,4 \%)$ or humanities $(0,5 \%)$ only account for few associations in this segment. Their attitudes towards science are moderate: They are rather interested in science, trust it and tend to think that it is important to be informed about it. But they do not often seek information about science, and their interest in 'citizen science' is only moderate.

Overall, their reservations and beliefs regarding science are not strongly pronounced. They think science improves our lives, might provide a full picture of the world, and is generally beneficial for society. But they do not believe science should have no constraints, or that it can solve every problem. The "Passive Supporters" support public funding and basic research, albeit less so than the "Critically Interested" and the "Sciencephiles". Like the previous segments, they think scientists should inform the public about their work.

4. The "Disengaged" $(n=141 ; 13,4 \%)$ are the smallest segment. They have the highest proportion of respondents that do not provide a single association with "science and research". Those who did thought mostly of medicine $(19,5 \%)$ and the natural sciences $(11,7 \%)$, with engineering $(4,8 \%)$, the social sciences $(2,2 \%)$ and humanities $(0,1 \%)$ remaining marginal. The 
"Disengaged" are also moderately in favor of basic research and public funding. But they perceive science more negatively than the other groups, and oppose the "Sciencephiles"' views in many respects. They consider science not to be important in their lives, almost never seek information about it, and are hardly interested in partaking in research. They have the lowest interest and trust in science, and are not convinced that it is important to be informed about it. They also have the lowest level of scientific literacy. They favour some research constraints and think that humanity relies too heavily on science.

--- TABLE 2 HERE ---

\subsection{Media and Information Use Patterns: The Segmented Audience of Science Communication}

In addition to their different perceptions of science, people grouped in the four segments differ sociodemographically and in their information and media use (cf. Table 2):

1. $61.6 \%$ of the "Sciencephiles" are male - the highest proportion among the segments. They also show the highest level of education and proximity to science of all groups. While they are the oldest segment ( 47.6 years), age does not differ significantly between the groups.

They use a broad range of sources to encounter scientific content - most often the internet, particularly on Wikipedia and institutional websites, whereas Facebook or Blogs are their least likely sources. They also encounter science often in newspapers and magazines and, on a lower level, on TV. Among all groups, they read science magazines most often.

In addition, they evaluate media reporting on science most positively in terms of trustworthiness, accuracy, comprehensibility etc., are the most attentive when scientific topics come up in the media, and also engage with science elsewhere: More than most other segments, they talk to friends and acquaintances about it, read science books and go to scientific museums and exhibitions.

Their motivations to engage with scientific content are high. No other group wants to participate in conversations about science and research as much. Their motives for doing so are intrinsic: The "Sciencephiles" are driven by personal curiosity and their willingness to better understand science and research. 
2. The "Critically Interested" are, again, similar to the "Sciencephiles" in many ways. They are highly educated, have a close proximity to science and a liberal-leaning political orientation. They are, however, significantly more religious than the "Sciencephiles".

In addition, they mostly share the "Sciencephiles"' patterns of media and information use. They use the same set of mass media, to similar degrees, tend to the same online and social media (with the exception of reading online newspapers and magazines less often) and use the same non-media sources to tend to scientific topics, such as talking to their peers or reading science books. Moreover, they do so for reasons very similar to those of the "Sciencephiles".

The main differences between the "Sciencephiles" and the "Critically Interested" lies in their evaluations of science-related media content. Not only are the "Critically Interested" less attentive towards such content, they are also more critical. For example, they do not think that the coverage is very extensive. Their evaluations of media coverage are closer to those of the "Passive Supporters".

3. The "Passive Supporters" are on average 45.9 years old, $55.8 \%$ of them are female, and their education levels are below the previous two segments.

As a general pattern, they rank below the people grouped in the "Sciencephiles" and "Critically Interested" segments, and above the "Disengaged". For example, their attentiveness to scientific content in the media is significantly higher than the "Disengaged's" but significantly lower than that of the other two segments. Also, they are most likely to encounter science through daily or weekly newspapers and magazines and on the internet, but each with the second lowest mean across clusters. Moreover, while they most often get in contact with science on Wikipedia, they only do so significantly more often than the "Disengaged" and significantly less than the other two segments. Their assessments of science reporting is mostly on par with the full sample means, i.e. on a moderate level. If anything, they do not fully agree that the reporting shows them science's relevance.

The "Passive Supporters" do not use non-mediated sources very often. If they do, they are most likely to talk about science with friends and acquaintances or visit zoos, aquariums or botanical gardens. Also, while they are curious about science and research, this number is significantly lower compared to the previous segments. 
4. Among respondents in the "Disengaged" segment, the proportion of women is the highest (63.4\%). The average age of this segment is 45.1 . They have, by far, the lowest level of education and the largest personal and professional distance to science.

Their low interest and critical perception of science translates into a low motivation to engage with science and research at all, and into having the fewest contacts with science across almost all mass media and online sources. The only sources they use as often as others regarding science are commercial TV - the "Disengaged's" main source -, commercial radio and Facebook. Apart from only rarely consuming science-related content, this segment is also the most critical towards this content, evaluating the trustworthiness and comprehensibility of media reporting of science comparatively negatively, and not thinking that the reporting makes science's relevance clear.

The "Disengaged" are also the least likely to talk about science with friends and acquaintances, to go to science events, and to read science books. The only non-mediated form of contact with science that is not significantly lower compared with other segments are visits to zoos, aquariums or botanical gardens.

\section{Conclusion}

Perceptions of science differ between sociodemographic groups. Segmentation analyses have the potential to focus on these differences and reconstruct latent patterns that divide populations into relatively similar groups. The study at hand provides such an analysis based on a representative survey of the Swiss population, and adds to it from the perspective of the "science of science communication": In addition to reconstructing segments, it assesses whether people categorized into these segments exhibit specific patterns of media and information use.

The analysis shows that four segments can be reconstructed with different perceptions of science, and that people in these segments inform themselves differently about science. Respondents in the predominantly male group of "Sciencephiles", with a strong interest and support for science, an extensive knowledge about it, and a pronounced belief in its potential, use a wide variety of sources intensively, particularly the internet. They evaluate media coverage of science positively, and engage with such issues also in conversations, events, by reading science books etc. The "Critically Interested", also with strong interest and support for science but with less trust in science's proponents and a more pronounced critical view on the limits of science, use media and online sources similar to the "Sciencephiles", but are more cautious towards these sources. The "Passive Supporters", the largest 
group, with moderate levels of interest, trust and knowledge and tempered but rather positive perceptions of science, use fewer sources, and less intensively, when it comes to science. For them, Wikipedia is particularly important. The least educated and predominantly female "Disengaged", making up the smallest segment, are not interested in science, have low scientific literacy, and harbour more critical views towards it - even though their general assessment is still supportive. When they encounter scientific issues in mass media or online, which rarely happens, it is most likely on commercial TV or radio.

These findings can be used, firstly, to assess theoretical assumptions about perceptions of science and science communication. They reiterate, that different perceptions of and attitudes towards science converge in different population segments, and that these segments have different sociodemographic loci (e.g. OST \& The Wellcome Trust, 2000). The equally extensive scientific literacy of the "Sciencephiles" and "Critically Interested" segments demonstrates that knowledge does not determine support for science, further disconfirming the "deficit model" of science communication (e.g. Kawamoto et al., 2013). At the same time, the segments underscore relationships between attitudinal variables that have been established in other studies, for example, that interest in science, scientific literacy and actively searching for information about science correlate positively (Ho et al., 2014).

Second, the results show that population segments differ also in their media repertoires. The results show that interest in and knowledge about science correlates with more frequent science-related information use (e.g. Nisbet et al., 2002). Moreover, segmentation studies are useful to monitor the degree of populations' fragmentation with regards to science-related attitudes and information patterns. Due to the changing media landscape, many scholars have warned that online and social media in which individuals configure their own information diets may lead to fragmented publics. Even though such fragmentations seem to be less pronounced than expected for other issues (e.g. Fletcher \& Nielsen, 2017), they could still be important for science and research - complex topics for which information is often acquired online (Brossard, 2013). Our study hints at such fragmentations, in that attitudinal patterns correspond to differences in information use. In turn, however, describing such differentiations in perceptions and information repertoires can used for communication efforts, whether these aim at informing, image-building, or targeting attitudinal or behavioral change (cf. Detenber et al., 2016, p. 7374). Designing such efforts should take into account that target audiences may differ, that different aims, messages and communicative channels need to be utilized (cf. Metag et al., 2017). 
Third, the findings broaden the base of science-related segmentation data beyond the few countries for which such analyses have been done. In doing so, they demonstrate specifics of the Swiss case: Despite clear attitudinal differences between the reconstructed segments, the results show that science is not a generally contentious issue in Switzerland. All segments groups are generally supportive of science, and there are no strong antagonists of science and research even though the "Critically Interested" or "Disengaged" may object to specific kinds of scientific research that, in their view, violates social, legal or ethical norms (like animal testing, cf. Roten, 2013). This general support for science and research differs from countries like the UK (e.g. Research Councils, 2008), and may be due to Switzerland's status of a knowledge economy which invests strongly in research and education. In addition, the results could also be interesting for analyses of the science-society nexus. In other fields, similar "segments have been validated as predictors of public support" for climate changerelated policies, and in that respect, belonging to a certain segment proved to be a "stronger predictor than demographics and political ideology" (Detenber et al., 2016, p. 4738). Our results are in line with this observation. While we exclusively clustered along 'psychographic' variables, the resulting differences in media and information use showed significant and recurring patterns across segments. A targeted effort of measuring the predictive value of segmentation analyses such as ours would certainly be worthwhile.

To do so, methodological advances would be helpful. Similar studies in other fields have employed discriminant analyses to identify the subsets of variables which best identify repondents' categorization into certain segments. On this basis, short survey instruments were developed (e.g. Maibach et al., 2011; Swim \& Geiger, 2017) to enrich other studies and to test the value of the segmentation beyond a narrow field. The present study would lend itself to the development of a short survey instrument.

Apart from survey studies, bolstering the segment descriptions by incorporating qualitative elements would be useful (cf. Hine et al., 2014). While standardized and partly tested survey tools exist to assess perceptions of science and the respective sources of information, details may remain hidden in such an analysis. For example, the "Sciencephiles" and the "Critically Interested", despite having differing perceptions of science, share a similar media diet with regards to science and research. Further elaboration could unearth important differences in their contact with science that go beyond general assessments of all science content. Eventually, given the considerable current changes in the relation between science and society (Fischhoff \& Scheufele, 2013; Schäfer, Kristiansen, \& Bonfadelli, 2015), it would certainly be worth to track potential changes in the makeup and size of the segments over time. 


\section{References}

Ajzen, I. (1989). Attitude structure and behavior. Attitude structure and function, 241-274.

Ajzen, I. (2001). Nature and Operation of Attitudes. Annu. Rev. Psychol., 52(1), 27-58. doi:10.1146/annurev.psych.52.1.27

Ajzen, I. (2002). Perceived Behavioural Control, Self-Efficacy, Locus of Control and the Theory of Planned Behaviour. Journal of applied social psychology, 32, 665-683.

Bamberg, S., \& Möser, G. (2007). Twenty years after Hines, Hungerford, and Tomera. Journal of environmental psychology, 27(1), 14-25.

Bauer, M. W. (2016). The Culture of Science Indicators. London: LSE.

BBVA foundation. (2011). International Study on Scientific Culture. Bilbao: BBVA.

Besley, J. C. (2013). The state of public opinion research on attitudes and understanding of science and technology. Bulletin of Science, Technology \& Society, 33(1-2), 12-20.

Brossard, D. (2013). New media landscapes and the science information consumer. Proceedings of the National Academy of Sciences. doi:10.1073/pnas.1212744110

Brossard, D., \& Scheufele, D. A. (2013). Science, New Media, and the Public. Science, 339(6115), 40-41. doi:10.1126/science.1232329

Bucchi, M. (2008). Of deficits, deviations and dialogues: Theories of Public Communication of Science. In M. Bucchi \& B. Trench (Eds.), Handbook of public communication of science and technology (pp. 57-76). London: Routledge.

Detenber, B., Rosenthal, S., Liao, Y., \& Ho, S. S. (2016). Audience Segmentation for Campaign Design. International Journal of Communication, 10, 23.

Dibb, S. \& Simkin, L. (2009). Bridging the segmentation theory/practice divide: Taylor \& Francis.

Durant, J. (2003). From Deficit to Dialogue. In

Engdahl, E., \& Lidskog, R. (2014). Risk, communication and trust. Public Understanding of Science, 23(6), 703-717.

Eurobarometer, S. (2005). Europeans, Science and Technology. European Commission, June,

Eurobarometer. (2001). Eurobarometer 55.2 - Europeans, Science and Technology. Brussels: European Union.

Eurobarometer. (2010). Special Eurobarometer 340: Science and Technology. Brussels: European Commission.

Eveland Jr, W. P., Hutchens, M. J., \& Shen, F. (2009). Exposure, attention, or "use" of news?. Communication Methods and Measures, 3(4), 223-244.

Eveland, W. P. (2001). The cognitive mediation model of learning from the news evidence from nonelection, off-year election, and presidential election contexts. Communication Research, 28(5), 571-601.

Fischhoff, B., \& Scheufele, D. A. (2013). The science of science communication. Proceedings of the National Academy of Sciences, 110, 14031-14032. doi:10.1073/pnas.1312080110

Fletcher, R., \& Nielsen, R. K. (2017). Are people incidentally exposed to news on social media? New Media \& Society, 1461444817724170 .

Fredin, E. S., Kosicki, G. M., \& Becker, L. B. (1996). Cognitive strategies for media use during a presidential campaign. Political Communication, 13(1), 23-42.

Gollwitzer M. (2012). Latent-Class-Analysis. In: Moosbrugger H., \& Kelava A. (eds). Testtheorie und Fragebogenkonstruktion. Berlin \& Heidelberg: Springer. 295-323.

Guenther, L., \& Weingart, P. (2017). Promises and reservations towards science and technology among South African publics. Public Understanding of Science, Online First.

Hine, D. W., Reser, J. P., Morrison, M., Phillips, W. J., Nunn, P., \& Cooksey, R. (2014). Audience segmentation and climate change communication. Wiley Interdisciplinary Reviews: Climate Change, 5(4), 441-459.

Hurtado, M. C., \& Cerezo, J. A. L. (2012). Political dimensions of scientific culture. Public Understanding of Science, 21(3), 369-384.

Kahlor, L., \& Rosenthal, S. (2009). If We Seek, Do We Learn? Science Communication, 30(3), 380-414. doi:10.1177/1075547008328798

Kahlor, L., Dunwoody, S., Griffin, R. J., \& Neuwirth, K. (2006). Seeking and processing information about impersonal risk. Science Communication, 28(2), 163-194.

Kawamoto, S., Nakayama, M., \& Saijo, M. (2013). A survey of scientific literacy to provide a foundation for designing science communication in Japan. Public Understanding of Science, 22(6), 674-690.

Kristiansen, S., Bonfadelli, H., \& Kovic, M. (2016). Risk Perception of Nuclear Energy After Fukushima. International Journal of Public Opinion Research. 
Lee, C.-j., Scheufele, D. A., \& Bruce V. Lewenstein. (2005). Public Attitudes toward Emerging Technologies. Science Communication, 27(2), 240-267.

Leiserowitz, A., Maibach, E., Roser-Renouf, C., \& Smith, N. (2010). Global Warming's Six Americas. New Haven: Yale University and George Mason University.

Leiserowitz, A., Maibach, E., Roser-Renouf, C., Feinberg, G., \& Howe, P. (2013). Global warming's six Americas, September 2012. Yale University and George Mason University. New Haven, CT: Yale Project on Climate Change Communication,

Linzer, D. A., Lewis, J. B., \& others. (2011). poLCA: An R package for polytomous variable latent class analysis. Journal of Statistical Software, 42(10), 1-29.

Lotenberg, L. D., Schechter, C., \& Strand, J. (2011). Segmentation and targeting. The SAGE handbook of social marketing, $125-135$.

Macedo-Rouet, M., Rouet, J.-F., Epstein, I., \& Fayard, P. (2003). Effects of Online Reading on Popular Science Comprehension. Science Communication, 25(2), 99-128. doi:10.1177/1075547003259209

Magidson, J., \& Vermunt, J. (2002a). Latent class models for clustering. Canadian Journal of Marketing Research, 20(1), 3643.

Magidson, J., \& Vermunt, J. (2002b). Latent class models. In D. Kaplan (Ed.), The Sage Handbook of Quantitative Methodology for the Social Sciences (pp. 175-198). Thousand Oaks, CA: Sage.

Maibach, E. W., Leiserowitz, A., Roser-Renouf, C., \& Mertz, C. K. (2011). Identifying like-minded audiences for global warming public engagement campaigns. Plos One, 6(3), e17571. doi:10.1371/journal.pone.0017571

Maibach, E. W., Weber, D., Massett, H., Hancock, G. R., \& Price, S. (2006). Understanding consumers' health information preferences development and validation of a brief screening instrument. Journal of Health Communication, 11(8), 717736.

McLachlan, G., \& Peel, D. (2004). Finite mixture models: Wiley \& Sons.

Mejlgaard, N., \& Stares, S. (2010). Participation and competence as joint components in a cross-national analysis of scientific citizenship. Public Understanding of Science, 19(5), 545-561.

Metag, J. (2017). Rezeption und Wirkung öffentlicher Wissenschaftskommunikation. In Forschungsfeld Wissenschaftskommunikation (pp. 251-274). Springer.

Metag, J., Füchslin, T., \& Schäfer, M. S. (2017). Global warming's five Germanys: A typology of Germans' views on climate change and patterns of media use and information. Public Understanding of Science, 26(4), 434-451.

Miller, J. D. (1983). Scientific literacy: A conceptual and empirical review. Daedalus, 112(2), 29-48.

Morrison, M., Duncan, R., Sherley, C., \& Parton, K. (2013). A comparison between attitudes to climate change in Australia and the United States. Australasian Journal of Environmental Management, 20(2), 87-100.

National Science Board. (2014). Science and Engineering Indicators 2014. Arlington: National Science Foundation.

Nisbet, M. C., Scheufele, D. A., Shanahan, J., Moy, P., Brossard, D., \& Lewenstein, B. V. (2002). Knowledge, Reservations, or Promise?. Communication Research, 29(5), 584-608.

Nisbet, M., \& Markowitz, E. M. (2014). Understanding public opinion in debates over biomedical research. Plos One, 9(2), e88473.

Noar, S. M., Benac, C. N., \& Harris, M. S. (2007). Does tailoring matter? Meta-analytic review of tailored print health behavior change interventions. Psychological Bulletin, 133(4), 673.

OECD. Revised Fields of Science and Technology. Retrieved from http://www.oecd.org/science/inno/38235147.pdf

OST \& Wellcome Trust. (2000). Science and the Public. London: Office of Science and Technology (OST) \& Wellcome Trust.

OST (2005). Science in Society. London: Department of Trade \& Industry, Office of Science and Technology.

Pardo, R., \& Calvo, F. (2002). Attitudes toward science among the European public. Public Understanding of Science, 11(2), 155-195.

Pardo, R., \& Calvo, F. (2004). The cognitive dimension of public perceptions of science. Public Understanding of Science, 13(3), 203-227.

Pew Research Center. (2013). Public's Knowledge of Science and Technology. Retrieved from http://www.peoplepress.org/2013/04/22/publics-knowledge-of-science-and-technology/

Prpic, K. (2011). Science, the public, and social elites. Public Understanding of Science, 20(6), 733-750.

Research Councils UK. (2008). Public Attitudes to Science 2008. London: Department of Innovation, Universities \& Skills.

Roser-Renouf, C., Maibach, E., Leiserowitz, A., Feinberg, G., \& Rosenthal, S. (2016). Faith, Morality and the Environment. Online: http://climatecommunication. yale. edu/publications/faith-morality-environment, 
Rössler, P. (2011). Skalenhandbuch Kommunikationswissenschaft. Wiesbaden: Springer.

Roten, F. C. von. (2013). Public perceptions of animal experimentation across Europe. Public Understanding of Science, 22(6), 691-703.

Schäfer, M. S. (2009). From Public Understanding to Public Engagement: An Empirical Assessment of Changes in Science Coverage. Science Communication, 30(4), 475-505.

Schäfer, M. S. (2012). Taking Stock: a Meta-Analysis of Studies on the Media's Coverage of Science. Public Understanding of Science, 21(6), 650-663. doi:10.1177/0963662510387559

Schäfer, M. S. (2016). Mediated Trust in Science. JCOM, 15, C02.

Schäfer, M. S. (2017). Wissenschaftskommunikation Online. In Forschungsfeld Wissenschaftskommunikation (pp. 275-293). Springer.

Schäfer, M. S., \& Taddicken, M. (2015). Mediatized Opinion Leaders. International Journal of Communication, 9, http://ijoc.org/index.php/ijoc/article/view/2778.

Schäfer, M. S., Kristiansen, S., \& Bonfadelli, H. (2015). Wissenschaftskommunikation im Wandel. Wissenschaftskommunikation im Wandel, 10-42.

Slater, M. D. (1996). Theory and method in health audience segmentation. Journal of Health Communication, 1(3), 267284.

Sunstein, C. (2009). Republic 2.0. Princeton \& London: Princeton University Press.

Sütterlin, B., Brunner, T. A., \& Siegrist, M. (2011). Who puts the most energy into energy conservation? Energy Policy, 39(12), 8137-8152.

Swim, J. K., \& Geiger, N. (2017). From Alarmed to Dismissive of Climate Change. Environmental Communication, 11(4), 568586. doi:10.1080/17524032.2017.1308409

Tsfati, Y., Cohen, J., \& Gunther, A. C. (2011). The Influence of Presumed Media Influence on News About Science and Scientists. Science Communication, 33(2), 143-166. doi:10.1177/1075547010380385

Vermunt, J. K., \& Magidson, J. (2016). Technical guide for Latent GOLD 5.1. Belmont: Statistical Innovations.

Wind, Y. (1978). Issues and advances in segmentation research. Journal of Marketing Research, 317-337.

Wissenschaft Im Dialog. (2015). Wissenschaftsbarometer 2015. Retrieved from http://www.wissenschaft-imdialog.de/projekte/wissenschaftsbarometer/

Yankelovich, D., \& Meer, D. (2006). Rediscovering market segmentation. Harvard business review, 84(2), 122. 
Table 1: Items used in our study

\begin{tabular}{|c|c|c|c|c|}
\hline Dimension & Items & $\mathbf{N}$ & $M$ & SD \\
\hline \multirow[t]{2}{*}{$\begin{array}{l}\text { Attitudes towards } \\
\text { Science \& Research } \\
\text { Cognitive }\end{array}$} & $\begin{array}{l}\text { Scientific Literacy } \\
\text { (index: 0-2; no/incorrect answer=0 pts., correct "likely"-answer=1 pt., correct } \\
\text { "definitely"-answer =2pts.) }\end{array}$ & 1051 & 1.23 & 0.36 \\
\hline & $\begin{array}{l}\text { How interested are you in science and research? } \\
(1=" \text { not at all" } \ldots 5=\text { ="very interested") }\end{array}$ & 1050 & 3.45 & 1.11 \\
\hline \multirow[t]{2}{*}{ Affective } & $\begin{array}{l}\text { Science and research play an important role in my life } \\
(1=" \text { do not agree at all" ... 5="agree strongly") }\end{array}$ & 1044 & 3.14 & 1.19 \\
\hline & $\begin{array}{l}\text { How high is your trust in science in general? } \\
(1=\text { "very low" ... 5="very high") }\end{array}$ & 1042 & 3.58 & 0.74 \\
\hline \multirow[t]{2}{*}{ Conative } & $\begin{array}{l}\text { I specifically search for information about science and research } \\
(1=" \text { do not agree at all" } \ldots 5=\text { " agree strongly") }\end{array}$ & 1048 & 3.13 & 1.35 \\
\hline & $\begin{array}{l}\text { I would like to partake in scientific research once } \\
(1=" \text { do not agree at all" } \ldots 5=\text { " agree strongly") }\end{array}$ & 1043 & 2.86 & 1.39 \\
\hline \multirow{7}{*}{$\begin{array}{l}\text { 'Reservations vs. } \\
\text { beliefs in the } \\
\text { promise of science' }\end{array}$} & $\begin{array}{l}\text { Science and technology can sort out any problem } \\
\left(1={ }^{\prime \prime} \text { do not agree at all" } \ldots 5=\text { "'agree strongly") }\right.\end{array}$ & 1049 & 2.16 & 1.01 \\
\hline & $\begin{array}{l}\text { Science and research make our lives better } \\
(1=" \text { do not agree at all" } \ldots 5=\text { ="agree strongly") }\end{array}$ & 1049 & 3.75 & 0.91 \\
\hline & $\begin{array}{l}\text { Science makes our ways of life change too fast } \\
(1=" \text { do not agree at all" } \ldots 5=\text { " agree strongly") }\end{array}$ & 1043 & 3.03 & 1.15 \\
\hline & $\begin{array}{l}\text { The benefits of science are greater than any harmful effects it may have } \\
(1=" \text { do not agree at all" ... 5="agree strongly") }\end{array}$ & 1017 & 3.11 & 1.05 \\
\hline & $\begin{array}{l}\text { Science should have no limits to what it is able to investigate } \\
\text { (1="do not agree at all" ... 5="agree strongly") }\end{array}$ & 1043 & 2.60 & 1.26 \\
\hline & $\begin{array}{l}\text { Science will eventually provide a full picture of how nature and the universe works } \\
\text { (1="do not agree at all" ... 5="agree strongly") }\end{array}$ & 1041 & 2.87 & 1.26 \\
\hline & $\begin{array}{l}\text { We rely too heavily on science } \\
(1=" \text { do not agree at all" } \ldots 5=\text { " agree strongly") }\end{array}$ & 1042 & 3.03 & 1.02 \\
\hline \multirow{7}{*}{$\begin{array}{l}\text { Subjective Norms } \\
\text { Desirable Relation } \\
\text { between Science \& } \\
\text { Society }\end{array}$} & $\begin{array}{l}\text { Scientific research is necessary even if there is no immediate application } \\
\text { (1="do not agree at all" ... 5="agree strongly") }\end{array}$ & 1044 & 4.02 & 1.03 \\
\hline & $\begin{array}{l}\text { Scientific research should be publicly funded } \\
\text { (1="do not agree at all" ... 5="agree strongly") }\end{array}$ & 1039 & 4.04 & 0.99 \\
\hline & $\begin{array}{l}\text { Scientists should inform the public about their work } \\
(1=" \text { do not agree at all" ... 5="agree strongly") }\end{array}$ & 1047 & 3.99 & 0.94 \\
\hline & $\begin{array}{l}\text { Scientists should listen more to what regular people think } \\
\text { (1="do not agree at all" ... 5="agree strongly") }\end{array}$ & 1039 & 3.29 & 1.23 \\
\hline & $\begin{array}{l}\text { Political decisions should be based on scientific findings } \\
\text { (1="do not agree at all" ... 5="agree strongly") }\end{array}$ & 1031 & 3.48 & 1.06 \\
\hline & $\begin{array}{l}\text { People like me should be involved in decisions about the topics scientists research } \\
\text { (1="do not agree at all" ... 5="agree strongly") }\end{array}$ & 1037 & 2.51 & 1.14 \\
\hline & $\begin{array}{l}\text { It is important to be informed about science and research } \\
(1=" \text { do not agree at all" } \ldots \text { 5="agree strongly") }\end{array}$ & 1048 & 3.90 & 0.98 \\
\hline $\begin{array}{l}\text { Total associations } \\
\text { (three per } \\
\text { respondent) with } \\
\text { "Science and } \\
\text { Research" }\end{array}$ & If you think about science and research, what topics first come to your mind? & 3153 & N.A. & N.A. \\
\hline \multirow[t]{6}{*}{ Sociodemographics } & Gender (percent female) & 1051 & 50.8 & - \\
\hline & Age (years) & 1051 & 46.3 & 17.90 \\
\hline & Education (percent tertiary education) & 1046 & 43.3 & - \\
\hline & Proximity to science (index: $0-4$ ) & 1049 & 1.59 & 1.26 \\
\hline & Religiosity (1="not at all religious" ... 5=" very religious") & 1047 & 2.72 & 1.25 \\
\hline & Political Orientation (1="left" ... 7="right") & 998 & 3.64 & 1.28 \\
\hline $\begin{array}{l}\text { Mass Media Con- } \\
\text { tact with Science } \\
\text { and Research }\end{array}$ & $\begin{array}{l}\text { How often do you come in contact with science and research via ... (always from } \\
1=" \text { never" ... } 5=" \text { very often") } \\
\text {... Swiss Public Television (SRF) }\end{array}$ & 1045 & 2.86 & 1.20 \\
\hline \multirow{6}{*}{ and Research } & ... Other Television & 1034 & 2.65 & 1.23 \\
\hline & ... Swiss Public Radio (SRF Radio) & 1040 & 2.36 & 1.29 \\
\hline & ... Other radio & 1036 & 1.64 & 1.00 \\
\hline & ... Daily/Weekly newspapers and magazines & 1042 & 3.28 & 1.22 \\
\hline & ... Science magazines & 1032 & 1.95 & 1.28 \\
\hline & ... Internet & 1045 & 3.12 & 1.38 \\
\hline
\end{tabular}




\begin{tabular}{|c|c|c|c|c|}
\hline $\begin{array}{l}\text { Online Contact with } \\
\text { Science and } \\
\text { Research }\end{array}$ & ... Online outlets of newspapers and magazines & 1042 & 2.23 & 1.33 \\
\hline & ... Online archives of television and radio channels & 1039 & 1.90 & 1.14 \\
\hline & ... Institutional websites (scientific, government, organizations) & 1041 & 2.31 & 1.28 \\
\hline & ... Facebook & 1044 & 1.55 & 1.06 \\
\hline & ... Blogs or message boards & 1042 & 1.54 & 0.90 \\
\hline & ... Wikipedia & 1040 & 2.72 & 1.40 \\
\hline & ... YouTube or similar video platforms & 1043 & 2.22 & 1.29 \\
\hline \multirow[t]{6}{*}{$\begin{array}{l}\text { Others Contact with } \\
\text { Science and } \\
\text { Research }\end{array}$} & $\begin{array}{l}\text { How often do you do one of the following ... (always from 1="never" ... 5="very } \\
\text { often") } \\
\text {... Visit museums and exhibitions covering science and research }\end{array}$ & 1049 & 2.47 & 1.08 \\
\hline & ... Visit zoos, aquariums or botanical gardens & 1050 & 2.71 & 1.13 \\
\hline & ... Attend events, talks, discussions concerning science and research & 1050 & 2.09 & 1.09 \\
\hline & ... Read nonfiction books on science and research & 1051 & 2.51 & 1.28 \\
\hline & ... Watch movies related to science and research in the cinema & 1049 & 2.32 & 1.18 \\
\hline & ... Talk about science and research with friends and acquaintances & 1051 & 3.11 & 1.12 \\
\hline $\begin{array}{l}\text { Patterns of } \\
\text { Information and } \\
\text { Media Use }\end{array}$ & $\begin{array}{l}\text { How attentive are you when media report on scientific topics? } \\
(1=" \text { not attentive at all" ... 5="very attentive") }\end{array}$ & 1050 & 3.12 & 0.98 \\
\hline \multirow[t]{5}{*}{$\begin{array}{l}\text { assessment of } \\
\text { media coverage }\end{array}$} & $\begin{array}{l}\text { Generally, do you think media coverage about science and research is ... (always } \\
\text { from } 1=" \text { do not agree at all" ... 5=" agree strongly") } \\
\text {... trustworthy }\end{array}$ & & & \\
\hline & & 1031 & 3.34 & 0.85 \\
\hline & ... able to show how science is relevant in my life & 1028 & 2.90 & 1.01 \\
\hline & ... comprehensible & 1025 & 3.38 & 0.93 \\
\hline & ... extensive & 1007 & 3.17 & 0.87 \\
\hline \multirow[t]{5}{*}{$\begin{array}{l}\text { motivations for } \\
\text { tending to } \\
\text { scientific content }\end{array}$} & $\begin{array}{l}\text { How important are the following reasons for you to deal with science and research? } \\
\text { (always from } 1=" \text { not important at all" ... 5="very important") } \\
\text {... to inform myself for school/work }\end{array}$ & 1044 & 3.47 & 1.27 \\
\hline & ... because I'm curious & 1051 & 3.86 & 1.08 \\
\hline & ... to better understand science and research & 1047 & 3.62 & 1.05 \\
\hline & ... to be able to participate when others talk about science and research & 1046 & 2.99 & 1.13 \\
\hline & ... to fact-check information & 1047 & 3.29 & 1.09 \\
\hline
\end{tabular}


Table 1: Additional description of segments

\begin{tabular}{|c|c|c|c|c|}
\hline & $\begin{array}{l}\text { Science- } \\
\text { philes } \\
(n=292) \\
\end{array}$ & $\begin{array}{l}\text { Critically } \\
\text { Interested } \\
(n=181)\end{array}$ & $\begin{array}{l}\text { Passive } \\
\text { Supporters } \\
(n=437)\end{array}$ & $\begin{array}{l}\text { Disengaged } \\
(n=141)\end{array}$ \\
\hline \multicolumn{5}{|l|}{ Sociodemographics } \\
\hline Gender (percent female) & $38.4^{\mathrm{a}, \mathrm{b}}$ & 48.8 & $55.8^{a}$ & $63.4^{\mathrm{b}}$ \\
\hline Age (years) & 47.6 & 46.3 & 45.9 & 45.1 \\
\hline Education (percent tertiary education) & $58.5^{\mathrm{a}, \mathrm{d}}$ & $58.8^{\mathrm{b}, \mathrm{e}}$ & $35.0^{\mathrm{a}, \mathrm{b}, \mathrm{c}}$ & $17.3^{\mathrm{c}, \mathrm{d}, \mathrm{e}}$ \\
\hline Proximity to science (index: $0-4$ ) & $2.20^{\mathrm{a}, \mathrm{d}}$ & $2.06^{\mathrm{b}, \mathrm{e}}$ & $1.28^{\mathrm{a}, \mathrm{b}, \mathrm{c}}$ & $0.69^{c, d, e}$ \\
\hline Religiosity (1="not at all religious" ... 5=" very religious") & $2.43^{\mathrm{a}, \mathrm{b}}$ & $2.81^{\mathrm{b}}$ & $2.85^{\mathrm{a}}$ & 2.76 \\
\hline Political Orientation (1="left" ... 7="right") & 3.56 & $3.31^{\mathrm{a}, \mathrm{b}}$ & $3.79^{a}$ & $3.7^{4 b}$ \\
\hline \multicolumn{5}{|l|}{$\begin{array}{l}\text { Contact with Science and Research via Mass Media (1="never" } \\
\text {... 5="very often") }\end{array}$} \\
\hline Swiss Public Television (SRF) & 2.99 & 2.70 & 2.89 & 2.70 \\
\hline Other Television & $2.82^{\mathrm{b}}$ & $2.64^{c}$ & $2.68^{\mathrm{a}}$ & $2.19^{\mathrm{a}, \mathrm{b}, \mathrm{c}}$ \\
\hline Swiss Public Radio (SRF Radio) & 2.36 & 2.32 & 2.43 & 2.21 \\
\hline Other radio & 1.67 & $1.41^{\mathrm{a}}$ & $1.69^{\mathrm{a}}$ & 1.69 \\
\hline Daily/Weekly newspapers and magazines & $3.63^{a, c}$ & $3.39^{d}$ & $3.23^{\mathrm{a}, \mathrm{b}}$ & $2.54^{b, c, d}$ \\
\hline Science magazines & $2.55^{\mathrm{a}, \mathrm{d}}$ & $2.19^{\mathrm{b}, \mathrm{e}}$ & $1.68^{\mathrm{a}, \mathrm{b}, \mathrm{c}}$ & $1.21^{\mathrm{c}, \mathrm{d}, \mathrm{e}}$ \\
\hline Internet & $3.76^{\mathrm{a}, \mathrm{d}}$ & $3.52^{\mathrm{b}, \mathrm{e}}$ & $2.87^{\mathrm{a}, \mathrm{b}, \mathrm{c}}$ & $2.04^{\mathrm{c}, \mathrm{d}, \mathrm{e}}$ \\
\hline \multicolumn{5}{|l|}{ Contact with Science and Research via Online Media } \\
\hline Online outlets of newspapers and magazines & $2.78^{\mathrm{a}, \mathrm{c}, \mathrm{d}}$ & $2.19^{c, e}$ & $2.08^{\mathrm{a}, \mathrm{b}}$ & $1.59^{\mathrm{b}, \mathrm{d}, \mathrm{e}}$ \\
\hline Online archives of television and radio channels & $2.24^{\mathrm{a}, \mathrm{b}}$ & $2.01^{c}$ & $1.76^{\mathrm{a}}$ & $1.45^{\mathrm{b}, \mathrm{c}}$ \\
\hline Institutional websites (scientific, government, organizations) & $3.00^{\mathrm{a}, \mathrm{d}}$ & $2.70^{\mathrm{b}, \mathrm{e}}$ & $1.95^{\mathrm{a}, \mathrm{b}, \mathrm{c}}$ & $1.44^{\mathrm{c}, \mathrm{d}, \mathrm{e}}$ \\
\hline Facebook & 1.58 & 1.41 & 1.64 & 1.41 \\
\hline Blogs or message boards & $1.73^{\mathrm{b}}$ & $1.57^{c}$ & $1.50^{\mathrm{a}}$ & $1.23^{\mathrm{a}, \mathrm{b}, \mathrm{c}}$ \\
\hline Wikipedia & $3.33^{\mathrm{a}, \mathrm{d}}$ & $3.04^{\mathrm{b}, \mathrm{e}}$ & $2.55^{\mathrm{a}, \mathrm{b}, \mathrm{c}}$ & $1.59^{\mathrm{c}, \mathrm{d}, \mathrm{e}}$ \\
\hline YouTube or similar video platforms & $2.51^{\mathrm{a}, \mathrm{c}}$ & $2.44^{\mathrm{d}}$ & $2.14^{\mathrm{a}, \mathrm{b}}$ & $1.59^{b, c, d}$ \\
\hline \multicolumn{5}{|l|}{$\begin{array}{l}\text { Other Contact with Science and Research (1="never" ... 5="very } \\
\text { often") }\end{array}$} \\
\hline Visit museums and exhibitions covering science and research & $2.81^{\mathrm{a}, \mathrm{d}}$ & $2.76^{\mathrm{b}, \mathrm{e}}$ & $2.35^{\mathrm{a}, \mathrm{b}, \mathrm{c}}$ & $1.82^{\mathrm{c}, \mathrm{d}, \mathrm{e}}$ \\
\hline Visit zoos, aquariums or botanical gardens & 2.73 & 2.71 & 2.73 & 2.60 \\
\hline $\begin{array}{l}\text { Attend events, talks, discussions concerning science and } \\
\text { research }\end{array}$ & $2.50^{\mathrm{a}, \mathrm{d}}$ & $2.47^{\mathrm{b}, \mathrm{e}}$ & $1.90^{\mathrm{a}, \mathrm{b}, \mathrm{c}}$ & $1.34^{\mathrm{c}, \mathrm{d}, \mathrm{e}}$ \\
\hline Read nonfiction books on science and research & $3.16^{\mathrm{a}, \mathrm{d}}$ & $3.10^{\mathrm{b}, \mathrm{e}}$ & $2.21^{\mathrm{a}, \mathrm{b}, \mathrm{c}}$ & $1.31^{\mathrm{c}, \mathrm{d}, \mathrm{e}}$ \\
\hline Watch movies related to science and research in the cinema & $2.64^{\mathrm{a}, \mathrm{d}}$ & $2.53^{\mathrm{b}, \mathrm{e}}$ & $2.25^{\mathrm{a}, \mathrm{b}, \mathrm{c}}$ & $1.61^{\mathrm{c}, \mathrm{d}, \mathrm{e}}$ \\
\hline Talk about science and research with friends and acquaintances & $3.65^{\mathrm{a}, \mathrm{d}}$ & $3.55^{b, e}$ & $2.91^{a, b, c}$ & $2.02^{\mathrm{c}, \mathrm{d}, \mathrm{e}}$ \\
\hline \multicolumn{5}{|l|}{ Patterns of Information and Media Use } \\
\hline $\begin{array}{l}\text { How attentive are you when media report on scientific topics? } \\
\text { (1=" not attentive at all" ... 5="very attentive") }\end{array}$ & $3.72^{\mathrm{a}, \mathrm{d}, \mathrm{e}}$ & $3.35^{b, d, f}$ & $2.92^{\mathrm{a}, \mathrm{b}, \mathrm{c}}$ & $2.17^{\mathrm{c}, \mathrm{e}, \mathrm{f}}$ \\
\hline \multicolumn{5}{|l|}{$\begin{array}{l}\text { Assessment of media coverage } \\
(1=" \text { do not agree at all" } \ldots 5=\text { "agree strongly") }\end{array}$} \\
\hline trustworthy & $3.53^{b, c}$ & $3.28^{b, d}$ & $3.36^{\mathrm{a}}$ & $2.94^{\mathrm{a}, \mathrm{c}, \mathrm{d}}$ \\
\hline able to show how science is relevant in my life & $3.38^{a, c, d}$ & $2.98^{c, e}$ & $2.77^{a, b}$ & $2.14^{\mathrm{b}, \mathrm{d}, \mathrm{e}}$ \\
\hline comprehensible & $3.83^{a, c, d}$ & $3.45^{c, e}$ & $3.24^{\mathrm{a}, \mathrm{b}}$ & $2.78^{\mathrm{b}, \mathrm{d}, \mathrm{e}}$ \\
\hline extensive & $3.29^{c, d}$ & $2.98^{\mathrm{a}, \mathrm{c}}$ & $3.27^{\mathrm{a}, \mathrm{b}}$ & $2.81^{b, d}$ \\
\hline \multicolumn{5}{|l|}{$\begin{array}{l}\text { Motivations for tending to scientific content (1="not important } \\
\text { at all" ... 5="very important") }\end{array}$} \\
\hline to inform myself for school/work & $3.90^{\mathrm{a}, \mathrm{d}}$ & $3.80^{\mathrm{b}, \mathrm{e}}$ & $3.33^{\mathrm{a}, \mathrm{b}, \mathrm{c}}$ & $2.60^{c, d, e}$ \\
\hline because I'm curious & $4.47^{\mathrm{a}, \mathrm{d}}$ & $4.30^{\mathrm{b}, \mathrm{e}}$ & $3.65^{\mathrm{a}, \mathrm{b}, \mathrm{c}}$ & $2.63^{\mathrm{c}, \mathrm{d}, \mathrm{e}}$ \\
\hline to better understand science and research & $4.23^{\mathrm{a}, \mathrm{d}, \mathrm{e}}$ & $3.93^{b, d, f}$ & $3.42^{\mathrm{a}, \mathrm{b}, \mathrm{c}}$ & $2.54^{\mathrm{c}, \mathrm{e}, \mathrm{f}}$ \\
\hline $\begin{array}{l}\text { to be able to participate when others talk about science and } \\
\text { research }\end{array}$ & $3.49^{a, c, d}$ & $3.10^{\mathrm{c}, \mathrm{e}}$ & $2.90^{\mathrm{a}, \mathrm{b}}$ & $2.10^{\mathrm{b}, \mathrm{d}, \mathrm{e}}$ \\
\hline to fact-check information & $3.70^{\mathrm{a}, \mathrm{d}}$ & $3.59^{\mathrm{b}, \mathrm{e}}$ & $3.13^{\mathrm{a}, \mathrm{b}, \mathrm{c}}$ & $2.57^{c, d, e}$ \\
\hline
\end{tabular}

Means in the same row that share superscripts differ at $p<.05$ in the post-hoc test (Scheffé). 


\section{Appendix}

\begin{tabular}{|c|c|c|c|c|}
\hline & $\begin{array}{l}\text { Science- } \\
\text { philes } \\
(n=292)\end{array}$ & $\begin{array}{l}\text { Critically } \\
\text { Interested } \\
\text { (n=181) }\end{array}$ & $\begin{array}{l}\text { Passive } \\
\text { Supporters } \\
\text { (n=437) }\end{array}$ & $\begin{array}{l}\text { Disengaged } \\
(n=141)\end{array}$ \\
\hline \multicolumn{5}{|l|}{ Attitudes towards Science \& Research } \\
\hline $\begin{array}{l}\text { Scientific Literacy } \\
\text { (index: } 0-2 \text {; no/incorrect answer=0 pts., correct "likely"-answer=1 pt., } \\
\text { correct "definitely"-answer =2pts.) }\end{array}$ & 1.36 & 1.40 & 1.13 & 1.07 \\
\hline $\begin{array}{l}\text { How interested are you in science and research? } \\
(1=" \text { not at all" ... 5="very interested") }\end{array}$ & 4.23 & 3.87 & 3.07 & 2.44 \\
\hline $\begin{array}{l}\text { Science and research play an important role in my life } \\
(1=" \text { do not agree at all" ... 5="agree strongly") }\end{array}$ & 4.06 & 3.61 & 2.89 & 1.45 \\
\hline $\begin{array}{l}\text { How high is your trust in science in general? } \\
(1=" \text { very low" ... 5="very high") }\end{array}$ & 4.11 & 3.38 & 3.54 & 2.81 \\
\hline $\begin{array}{l}\text { I specifically search for information about science and research } \\
\text { (1="do not agree at all" ... 5="agree strongly") }\end{array}$ & 4.04 & 3.99 & 2.66 & 1.57 \\
\hline $\begin{array}{l}\text { I would like to partake in scientific research once } \\
(1=" \text { do not agree at all" } \ldots 5=\text { "agree strongly") }\end{array}$ & 3.68 & 3.38 & 2.61 & 1.26 \\
\hline \multicolumn{5}{|l|}{ 'Reservations vs. beliefs in the promise of science' } \\
\hline $\begin{array}{l}\text { Science and technology can sort out any problem } \\
\text { (1="do not agree at all" ... 5="agree strongly") }\end{array}$ & 2.72 & 1.29 & 2.32 & 1.68 \\
\hline $\begin{array}{l}\text { Science and research makes our lives better } \\
(1=" \text { do not agree at all" } \ldots \text { 5="agree strongly") }\end{array}$ & 4.46 & 3.48 & 3.68 & 2.85 \\
\hline $\begin{array}{l}\text { Science makes our ways of life change too fast } \\
\text { (1="do not agree at all" } \ldots 5=\text { " agree strongly") }\end{array}$ & 2.99 & 2.97 & 3.14 & 2.82 \\
\hline $\begin{array}{l}\text { The benefits of science are greater than any harmful effects it may } \\
\text { have } \\
\text { (1="do not agree at all" ... 5="agree strongly") }\end{array}$ & 3.66 & 2.57 & 3.10 & 2.65 \\
\hline $\begin{array}{l}\text { Science should have no limits to what it is able to investigate } \\
\text { (1="do not agree at all" ... 5="agree strongly") }\end{array}$ & 3.46 & 1.60 & 2.71 & 1.75 \\
\hline $\begin{array}{l}\text { Science will eventually provide a full picture of how nature and the } \\
\text { universe works ( } 1=\text { "do not agree at all" ... 5="agree strongly") }\end{array}$ & 3.37 & 1.79 & 3.12 & 2.43 \\
\hline $\begin{array}{l}\text { We rely too heavily on science } \\
(1=\text { "do not agree at all" } \ldots 5=\text { "agree strongly") }\end{array}$ & 2.89 & 3.17 & 3.08 & 3.01 \\
\hline \multicolumn{5}{|l|}{ Subjective/Informational Norms } \\
\hline $\begin{array}{l}\text { Scientific research is necessary even if there is no immediate } \\
\text { application } \\
\text { (1="do not agree at all" ... 5="agree strongly") }\end{array}$ & 4.56 & 4.46 & 3.76 & 3.09 \\
\hline $\begin{array}{l}\text { Scientific research should be publicly funded } \\
\text { (1="do not agree at all" ... 5="agree strongly") }\end{array}$ & 4.77 & 4.25 & 3.77 & 3.04 \\
\hline $\begin{array}{l}\text { Scientists should inform the public about their work } \\
(1=" \text { do not agree at all" } \ldots 5=\text { ="agree strongly") }\end{array}$ & 4.47 & 4.25 & 3.81 & 3.24 \\
\hline $\begin{array}{l}\text { Scientists should listen more to what regular people think } \\
\text { (1="do not agree at all" ... 5="agree strongly") }\end{array}$ & 3.06 & 3.23 & 3.40 & 3.54 \\
\hline $\begin{array}{l}\text { Political decisions should be based on scientific findings } \\
\text { (1="do not agree at all" ... 5="agree strongly") }\end{array}$ & 4.03 & 3.75 & 3.29 & 2.56 \\
\hline $\begin{array}{l}\text { People like me should be involved in decisions about the topics } \\
\text { scientists research ( } 1=\text { "do not agree at all" ... 5="agree strongly") }\end{array}$ & 2.65 & 2.59 & 2.61 & 1.82 \\
\hline $\begin{array}{l}\text { It is important to be informed about science and research } \\
(1=" \text { do not agree at all" } \ldots 5=\text { "agree strongly") }\end{array}$ & 4.61 & 4.27 & 3.63 & 2.81 \\
\hline \multicolumn{5}{|c|}{ Total associations (three per respondent) with "Science and Research" (percent) } \\
\hline Natural Science & 22.5 & 22.6 & 17.9 & 11.7 \\
\hline Engineering and Technology & 13.2 & 12.0 & 9.5 & 4.8 \\
\hline Medicine and Health Sciences & 20.7 & 21.8 & 22.3 & 19.5 \\
\hline Agricultural Sciences & 1.3 & 2.4 & 1.7 & 1.6 \\
\hline Social Sciences & 5.3 & 6.9 & 3.4 & 2.2 \\
\hline Humanities & 1.0 & 0.7 & 0.5 & 0.1 \\
\hline Other Association & 6.7 & 3.7 & 5.8 & 5.6 \\
\hline No Association & 29.4 & 29.9 & 38.9 & 54.6 \\
\hline
\end{tabular}


